\title{
EFFECT OF PRETREATMENT WITH TRICRESYLPHOSPHATES AND PHENOBARBITAL ON THE METABOLISM AND TOXICITY OF PROCAINE IN RATS
}

\author{
Tetsuo SATOH ${ }^{1}$ and Kayoko MOROI \\ Department of Experimental Pharmacology, Research Institute for \\ Chemobiodynamics, Chiba University, Narashino, Chiba 275, Japan \\ Accepted October 7.1976
}

\begin{abstract}
We examined the effects of pretreatment with phenobarbital and tricresylphosphates, TOCP and TCP, on the metabolism and toxicity of procaine in rats. $A$ single administration of procaine at a dose of $250 \mathrm{mg} / \mathrm{kg}$ intraperitoneally to adult rats caused convulsion, however, phenobarbital $(80 \mathrm{mg} / \mathrm{kg}$ intraperitoneally daily, 4 days $)$ pretreatment protected against the toxicity of procaine. In contrast, pretreatment of rats with TOCP $(10 \mathrm{mg} / \mathrm{kg}$ per os $)$ or TCP $(10 \mathrm{mg} / \mathrm{kg}$ per os) revealed a higher incidence of toxicity as compared to control rats. Mortality in procaine-treated rats was significantly decreased with phenobarbital-pretreatment and, conversely, increased with TOCP and TCP. Paralysis, convulsion and death were induced at the brain level of procaine of $0.303: 0.025,0.480 \div 0.026$ and $0.565^{\prime} 0.018$ :mole/g brain wet weight, respectively. Toxic effects of procaine were, therefore, concluded to be due to the accumulation of the drug in the brain.
\end{abstract}

It has been widely accepted that liver esterases appear to be more active in the metabolism of procaine than the plasma enzymes $(1-5)$. Our previous studies have shown that a liver microsomal arylamidase is responsible for the hydrolysis of several drugs possessing an amido bond and ester link such as procaine $(6,7)$. In addition, it was found that metabolism of the drug is inhibited by pretreatment with organophosphates (OP) (7-9) and conversely, stimulated by phenobarbital sodium (PB) pretreatment $(7,10)$.

The present study was undertaken to determine if toxic interactions occurred when OPor $\mathrm{PB}$-pretreated rats were challenged with procaine.

\section{MATERIALS AND METHODS}

\section{Animals and drug treatment}

Male Wistar rats weighing 200 to $250 \mathrm{~g}$ were used throughout the present study and were maintained on a commercial chow and water ad libitum. In the pretreatment studies, rats were given PB ( $80 \mathrm{mg} / \mathrm{kg}$ i.p. daily, 4 days), tricresylphosphate (TCP, $10 \mathrm{mg} / \mathrm{kg} \mathrm{p.o.)}$ and triorthocresylphosphate (TOCP, $10 \mathrm{mg} / \mathrm{kg}$ p.o.). Procaine hydrochloride was given i.p. $2 \mathrm{hr}$ after OP-pretreatment or $24 \mathrm{hr}$ after the final injection of $\mathrm{PB}$

Paralysis, convulsion and death were used as indices of procaine toxicities. Onset of paralysis was defined only when rats began to show loss of the righting reflex.

1 Present address: Department of Biochemical Pharmacology, Faculty of Pharmaceutical Sciences, Chiba University, Chiba 280 , Japan. To whom requests for reprints should be sent. 
Each group included at least ten animals.

Determination of procaine and p-aminobenzoic acid

Procaine and $p$-aminobenzoic acid (PABA) levels in tissues were assayed by the method of Ting et al. (11). Blood samples ( $1-2 \mathrm{ml})$ were quickly obtained from the heart immediately after death and mixed with $10 \%$ trichloracetic acid (TCA) to inhibit the enzymatic hydrolysis of procaine. Tissues were also homogenized in TCA as soon as possible after sacrifice.

Assay of procainesterase activity

For assay of procainesterase activity animals were sacrificed by decapitation at various time intervals after procaine injection, tissues were removed and homogenized in ice-cold $1.15 \% \mathrm{KCl}$ in a glass homogenizer with a Teflon pestle. Procainesterase activity was assayed as follows: the incubation mixture consisting of $1 \mathrm{ml}$ of procaine $\left(2 \times 10^{-3} \mathrm{M}\right)$ in $0.2 \mathrm{M}$ Tris- $\mathrm{HCl}$ buffer, $\mathrm{pH} 8.0,0.5 \mathrm{ml}$ enzyme source and enough redistilled water to make a final volume of $2.0 \mathrm{ml}$ was incubated at $37^{\circ} \mathrm{C}$ for $30 \mathrm{~min}$ in air. The amount of PABA produced and procaine remaining were measured as described earlier (11). Enzyme activity was expressed as / $/$ moles PABA formed $/ \mathrm{g}$ tissue wet wt. $/ 30 \mathrm{~min}$.

\section{RESULTS}

Effect of pretreatment of rats with tricresylphosphates and phenobarbital on the procainc toxicity

Table 1 shows that the acute toxicity of procaine given i.p. was potentiated by pretreatment of rats with OP. In contrast, convulsion produced by procaine administration at a dose of $250 \mathrm{mg} / \mathrm{kg}$ was significantly less in PB-pretreated rats than in control animals.

After the injection of $250 \mathrm{mg} / \mathrm{kg}$ of procaine, the mean time interval between injection and occurrence of the first paralysis was not significantly different between control and OP-pretreated animals, however, duration time of convulsion was about $32.3 \mathrm{~min}$ in control rats and 47.7 min in TOCP-pretreated animals, respectively. In the pretreatment with PB,

TABLE 1. Effect of pretreatment of rats with tricresylphosphates and phenobarbital on the procaine toxicity

\begin{tabular}{lcccc}
\hline Compound & Onset & duration & $\begin{array}{c}\text { Duration time of } \\
\text { convulsion (min) }\end{array}$ & $\begin{array}{c}\text { Mortality } \\
(\%)\end{array}$ \\
Control & $5.50 \div 0.43(16 / 16)$ & $32.30 \pm 1.05(16 / 16)$ & $13.09 \pm 1.12(16 / 16)$ & 0 \\
TOCP & $4.58 \div 0.69(12 / 12)$ & $47.66 \pm 2.48(3 / 12)$ & $31,35(2 / 12)$ & 75 \\
TCP & $4.10 \div 0.27(10 / 10)$ & $38.80+1.85(5 / 10)$ & $20.20 \pm 2.05(5 / 10)$ & 50 \\
PB & $7.01 \pm 0.87(7 / 15)$ & $11.00-1.78(7 / 15)$ & not observed $(0 / 15)$ & 0
\end{tabular}

Procaine $(250 \mathrm{mg} / \mathrm{kg}$ i.p.) was administered either $2 \mathrm{hr}$ after pretreatment with TOCP (10 mg/kg p.o.) and TCP (10 mg/kg p.o.) or $24 \mathrm{hr}$ after the final injection of PB ( 80 $\mathrm{mg} / \mathrm{kg}$ i.p. daily, 4 days). Numbers in parentheses indicate number of rats intoxicated/number of rats used. Figures represent mean + S.l. 
duration time of paralysis was markedly shortened and there were no deaths.

Changes in tissue concentrations of procaine and p-aminobenzoic acid in rats after pretreatment with organophosphates and phenobarbital

Tissue concentrations of procaine and its major metabolite, PABA, at the moment of death or $1.5 \mathrm{hr}$ after procaine injection were studied in control, $\mathrm{PB}$ - and OP-pretreated rats. The results presented in Table 2 demonstrated that the procaine level in the brain was about five-fold higher in the OP-pretreated rats, while such was one-fourth lower in PB-pretreated rats, as compared with the controls.

TABLE 2. Changes in tissue concentrations of procaine and $p$-aminobenzoic acid in rats after pretreatment with tricresylphosphates and phenobarbital:

\begin{tabular}{|c|c|c|c|c|}
\hline \multirow{2}{*}{ l'retreatment } & \multicolumn{2}{|c|}{ Procainel, } & \multicolumn{2}{|c|}{ PABA } \\
\hline & Brain & Liver & Brain & Liver \\
\hline None & $0.110 \cdot 0.018$ & $0.082: 0.011$ & $0.045 \ldots 0.004$ & $0.468-0.032$ \\
\hline 'TOCP & $0.594-0.013$ & $1.664: 0.106$ & $0.038: 0.006$ & $0.152 \pm 0.025$ \\
\hline TCP & $0.591 \cdots 0.016$ & $1.254+0.197$ & $0.018=0.002$ & $0.166 \pm 0.002$ \\
\hline PB & $0.023-0.003$ & $0.022 \div 0.004$ & $0.009--0.001$ & $0.109-0.008$ \\
\hline
\end{tabular}

a, Procaine (250 $\mathrm{mg} / \mathrm{kg}$ i.p.) was administered either 2 hr after pretreatment with TOCP (10 mg/kg p.o.) and TCP (10 $\mathrm{mg} / \mathrm{kg}$, p.o.) or $24 \mathrm{hr}$ after the final injection of PB (80) $\mathrm{mg} / \mathrm{kg}$ i.p. daily, 4 days). b, Procaine and PABA concentrations in tissucs were determined at the moment of death or $1.5 \mathrm{hr}$ after procaine administration. Values are expressed as :mole/g tissue wet wt.

Relationship between procaine toxicity and concentrations of procainc and p-aminobenzoic acid in rat brain

At $1.5 \mathrm{hr}$ after procaine injection, rats showing paralysis, convulsion and no toxic signs were sacrificed and procaine and PABA concentrations in brain were mcasured. Rats which died within $1.5 \mathrm{hr}$ after procaine injection were also used for determination of procaine and PABA levels at the moment of death. As shown in Table 3, paralysis, convulsion and death were found to be induced at the brain level of procaine of $0.303+0.025,0.480+0.026$ and $0.565 \div 0.018, \iota$ mole/g brain wet wt., respectively.

TABLE 3. Relationship between procaine toxicity and concentrations of procaine and $p$-aminobenzoic acid in rat brain

\begin{tabular}{|c|c|c|c|c|}
\hline Toxicity & Procaine" & $\mathrm{P}^{\prime}$ & PABA: & $\mathbf{P}$ \\
\hline No change & $0.185 \pm 0.014$ & - & $0.011 \pm 0.003$ & --- \\
\hline Paralysis & $0.303-0.025$ & 0.01 & $0.026: 0.003$ & 0.05 \\
\hline Convulsion & $0.480 \div 0.026$ & $\therefore 0.001$ & $0.037: 0.005$ & 0.05 \\
\hline Death & $0.565 \pm 0.018$ & 0.05 & $0.032 \perp 0.001$ & $\therefore 0.01$ \\
\hline
\end{tabular}

a, Values are expressed as /mole/g brain wet wh. Mean S.E. b, Difference between rats intoxicated and rats with no change were compared by Student's $t$-test. Procaine and PABA concentrations at the moment of death or $1.5 \mathrm{hr}$ after procainc injection 250 $\mathrm{mg} / \mathrm{kg}$, i.p.) were determined. 
TARLE 4. Changes in liver microsomal procainesterase activity of rats after administration of phenobarbital or organophosphates:

\begin{tabular}{lclcr}
\hline $\begin{array}{c}\text { Treatment } \\
\text { None }\end{array}$ & Dose $(\mathrm{mg} / \mathrm{kg})$ & $\begin{array}{l}\text { Procainesterase } \\
\text { activity }\end{array}$ & $\mathrm{P}^{\mathrm{b}}$ & $\%$ of control \\
PB & & $5.16 \pm 0.26(20)$ & - & 100.0 \\
TOCP & 10 & $6.44-0.37(11)$ & 0.01 & 149.2 \\
TCP & 10 & $0.13-0.03(20)$ & -0.001 & 2.5 \\
\hline
\end{tabular}

a, Animals were treated with either TOCP, TCP or PB and were sacrificed $2 \mathrm{hr}$ later.

$b$, Procainesterase activity was expressed as /moles PABA formed/g liver wet wt./30 min. Figures in parentheses indicate number of animals used in each experiment. c. Difference between treated and control values were compared by Student's $t$-1est.

Changes in liver microsomal procainesterase activity of rats after administration of phenobarbital or organophosphates

As shown in Table 4, the liver procainesterase was induced in PB-treated rats, conversely, the enzyme activity of OP-pretreated rats was significantly inhibited. These changes in liver microsomal procainesterase activity of rats by pretreatment with PB or OP were closely related to the severity of procaine toxicity in rats.

\section{DISCUSSION}

Recently, there has been increasing interest in one drug or chemical affecting the metabolism of a second drug, and Sher (12) and Conney and Burns (13) reviewed literature reports on drug-drug and drug-chemical interactions. Many of the anticholinesterase insecticides have been reported to cause a change in the rate of drug metabolism (14).

The present studies show that PB-pretreated rats exhibited a significantly higher protection against the toxic effects of procaine. In addition, we observed that there was a good correlation between the hydrolytic inactivation of procaine in the liver and the incidence of the toxicity. The observations reported in this study may be of some clinical importance. Procaine for local anesthesia has been widely used in humans. The prolonged use of PB, which is well known to stimulate hepatic esterase as well as drug metabolizing enzymes in liver microsomes, decreases the toxicity of procaine. Our findings herein should be considered when procaine is used for patients on PB or exposed to OP, because PB is known to decrease the effectiveness as well as toxicities of procaine and, conversely, OP induces a severe toxicity of the drug.

Acknowledgement: TOCP $(99.8 \%$ pure) and TCP $(99 \%)$ were kindly donated by Asahi Glass Co., Ltd., Tokyo, Japan.

\section{REFERENCES}

1) Krisch, K.: Biochem. Z. 337, 546 (1963)

2) Brodeur, J.: Rev. Canad. Biol. 26, 135 (1967)

3) LeE, R.M. AND Livett, B.H.: Biochem. Pharmacol. 16, 1757 (1967)

4) Kaiser, S.C., Kelvington, E.J., Kunig, R. and Randole, M.M.: J. Pharmacol. exp. Ther. $164,396(1968)$ 
5) Live[t, B.H. And Let, R.M.: Biochem. Pharmacol. 17, 385 (1968)

6) SATOH. T. AND Mokor, K.: Biochem. Pharmacol. 21, 3111 (1972)

7) Morol, K. ANd SATOH, T.: Biochem. Pharmacol. 24, 1517 (1975)

8) SАTOH, T.: Life Sci. 13, 1181 (1973)

9) Satoh, T. and Morol, K.: Toxicol. appl. Pharmacol. 25, 553 (1973)

10) SATOH, T. AND MOROI, K.: Life Sci. 12, 169 (1973)

11) Ting, K.S., COON, J.M. AND CONwAY, A.C.: J. Lab. clin. Med. 34, 822 (1949)

12) Sher, S.P.: Toxicol. appl. Pharmacol. 18, 780 (1971)

13) Conney, A.H. and Burns, J.J.: Science 178, $576(1972)$

14) Sritzel, R.E., Stevfens, J.T. and MCPhillips, J.J.: Drug Mejab. Rev. 1, 229 (1972) 